\title{
[63 64]縮合性樹脂に関する研究
}

第 4 報 ナイロン共絹合物について

(1952年1月11日受理)

井上良 三*

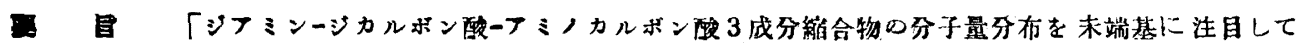
分子を 3 檑に分類して論じた。得られた関保式にジアミンージカルボン酸のみの綃合としての条件を代入す ると,以前に Flory によって求められた関釈に門站する。」

ナイロンは通常ジアンとジカルボン酸の共繀合からつくられるが，この繀合は交互に扎こる外はないの でよい絬晶性の高分子が得られることはよく知られているところである。ところがこれに第三の単是体を混 入して共蛨合するとその配列は乱されるであるら。今第三の単量体としてアミノカルボン酸であるとする。 ミーカプロラクタムの開環したものはこの一種であるが, ラクタム自身の反応性には少しく買なる点があり, これを考えない方がよい。この種ナイロン共縮合物には種々の用途が報ぜられている。

\section{[I]分子量分布}

今単量体につレて, ジアミンを $A_{1}$ 種, ジカルボン酸を $B_{1}$ 種, アミノカルボン酸を $C_{1}$ 種として 区別し，それぞれ初めに $A, B$ 及び $C \mathrm{~mol}$ をとるものとする。反応は分子端でおこるのであるから， この場合は分子端の相違につんての区別をしておかなければならない。任意の縮合後でも結局 $\mathrm{NH}_{2}$ $\mathrm{NH}_{2}, \mathrm{HOOC}-\mathrm{COOH}, \mathrm{NH}_{2}-\mathrm{COOH}$ の3種に区別できるから，一般に n-mer であることを，それぞ れ $A_{n}, B_{n}, C_{n}$ で示し，その存在数（モル）を $h_{A n}, h_{B n}$ 及び $h_{C n}$ と区別する。

さて，反応速度恒数につんてはなんら区別しない 2 分子反応とすると，反店自身は次のように未端 基だけに注目して行けばよん。

$$
-\mathrm{NH}_{2}+-\mathrm{COOH} \underset{\rightarrow}{\stackrel{k}{\rightarrow}}-\mathrm{NHOC}-+\mathrm{H}_{2} \mathrm{O}
$$

上式で $-\mathrm{NH}_{2}$ 基に対し反応す心゙き $-\mathrm{COOH}$ 基は， $B_{n}$ は 1 分子に 2 個， $C_{n}$ は 1 個持っている。 よってアミノ基に対し $B_{n}$ あるいは $C_{n}$ が反応する確率 $x_{B n}$ 及び $x_{C n}$ は次のようである。

$$
\begin{aligned}
& x_{B n}=\frac{2 h_{B n}}{2 \sum_{1}^{\infty} h_{B n}+\sum_{1}^{\infty} h_{\mathrm{c}_{n}}}=\frac{2 h_{B n}}{2 B+C-\alpha} \\
& x_{C n}=\frac{h_{C n}}{2 B+C-\alpha}
\end{aligned}
$$

もちろん $\sum_{1}^{\infty}\left(x_{B n}+x_{C n}\right)=1$ である。また $\alpha$ の定義は以前に同じ。

同檨なことが $-\mathrm{COOH}$ に対する $-\mathrm{NH}_{2}$ 基の反忘につんてもんえる。これを $y$ で示すと，

$$
\begin{aligned}
& y_{A n}=\frac{2 h_{A n}}{\sum_{1}^{\infty}\left(2 h_{A n}+h_{C n}\right)}=\frac{2 h_{A n}}{2 A+C-\alpha} \\
& y_{C_{n}}=\frac{h_{C n}}{2 A+C-\alpha}, \sum_{n=1}^{\infty}\left(y_{A n}+y_{C_{n}}\right)=1
\end{aligned}
$$

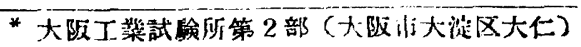


こちして2分子反応の組合せはその確率で次のように示されることが今迄と少し遙うところである。

$$
\sum_{n=1}^{\infty}\left(x_{B n}+x_{C_{n}}\right)\left(y_{A n}+y_{C_{n}}\right)=1
$$

これらの成保式から $d h n / d \alpha$ は以前とは少しく遼ってあらわれてくる。

一般に。

$$
\begin{aligned}
& \frac{d h_{A n}}{d \alpha}=-y_{A n}+\sum_{i=1}^{n-1} y_{A(n-1)} x_{C i} \\
& \frac{d h_{B n}}{d \alpha}=-x_{B_{n}}+\sum_{i=1}^{n-1} x_{B(n-i)} y_{C i} \\
& \frac{d h_{C n}}{d \alpha}=-x_{C n}-y_{C n}+\sum_{i=1}^{n-1} x_{B(n-i)} y_{A i}+\sum_{i=1}^{n-1} x_{C(n-1)} y_{C i}
\end{aligned}
$$

要するに $A_{n}, B_{n}$ に関しては同形の関係式であるが， $C_{n}$ のみいずれの相手とも反応するから形 が少し蚂ってくるのである。

この解は次のようになるり。

$$
\begin{aligned}
h_{A n}= & \sum_{i=0}^{n-1} \frac{(i+1)}{(2 i+2) !} \frac{n !}{(n-2 i-1) !} \frac{(2 A)^{i+1}(2 B)^{i} C^{n-(2+1)}}{(2 B+C)^{n-1}}(1-p)^{2} p^{n-1} \quad(5)-(1) \\
h_{B n}= & \sum_{i=0}^{n-1} \frac{(i+1)}{(2 i+2) !} \frac{n !}{(n-2 i-1) !} \frac{(2 B)^{i+1}(2 A)^{i} C^{n-(2 i+1)}}{(2 A+C)^{n-1}}(1-q)^{2} q^{n-1} \quad(5)-(2) \\
h_{C n}= & \sum_{i=0}^{\sum^{n}} \frac{n !}{(2 i) !(n-2 i) !} \frac{(2 A)^{i}(2 B)^{i} C^{n-2 i}}{(2 A+C)^{\frac{n-1}{2}}(2 B+C)^{\frac{n-1}{2}}(1-p)(1-q) p^{\frac{n-1}{2}} q^{n-1} \quad(5)-(3)} \\
& \text { ただし, } p=\alpha /(2 A+C), q=\alpha /(2 B+C)^{n}
\end{aligned}
$$

p及び $q$ はそれぞれ $\mathrm{NH}_{2}$ 基及しで酸基に関した反応度である。!

上式を籣単化して見る。

$A=B=0, C=1$ (モル) とすれば (5)一-(1)，(5)一-(2)は共になくなり，(5)一-(3)のみ残り， $p=q$ であるから,

$$
h_{C n}=(1-p)^{\mathrm{s}} p^{n-1}
$$

普通の 2 官能性単一縮合の分布である。

また $C=0, A+B=1$ (モル)のときは（5）式におんて,C の零乘の項のみ残るから， $h_{A n}$ 及び $h_{B n}$ につレては $n$ が奇数であるときの $n=2 i+1$ の項つみ残り, $h_{C n}$ につんては $n$ が偶数のとき の $n=2 i$ の項のみが残る。即ち次のようである。

$$
n \text {; 奇数 }\left\{\begin{array}{l}
h_{A n}=\frac{A^{\frac{n+1}{2}}}{B^{\frac{n-1}{2}}}(1-p)^{2} p^{n-1} \\
h_{B n}=\frac{B^{\frac{n+1}{2}}}{A^{\frac{n-1}{2}}}(1-q)^{2} q^{n-1}
\end{array}\right.
$$




$$
n \text {; 偶数 }\left\{h \mathrm{c}_{n}=2(A B)^{\frac{1}{2}}(1-p)(1-q) p^{\frac{n-1}{2}} q^{\frac{n-1}{2}}\right.
$$

これは Flory によって“odd A", “odd B”及び “even”分子と呼ばれたものの分布式に相 当する。ただ (6)-(1) 式だけは符䒓が氏の式上合致しない点がある2)。(6) 式でさらに $A=B=1 / \%$ なれば, $n$ の偶数及び奇数を通じて，全 $n$ 量体数はもちろん $(1-p)^{2} p^{n-1}$ となってくる。

さらに（5）式におんて $\mathrm{NH}_{2}$ 基あるいは $\mathrm{COOH}$ 基いずれか一方が過剩に使用されたときは $p$ あ るいは $q$ のいずれかが先に 1 に達し，最後には $h_{B c}$ あるいは $h_{A c}$ のいずれか一方だけが残る。な お（5）式の $\Sigma$ を取り去ったものは，i を特定とした，それぞれ $A_{i+1} B_{i} C_{n-(2 i+1)}, A_{i} B_{i+1} C_{n-(2 i+1)}$ 及び $A_{i} B_{i} C_{n:-2 i}$ なる分子の数を示す。

\section{〔II〕縮合物分子中の異つた結合}

実例はジアミンージカルボン酸はナイロン壏として使われることが多い。

このようなときは $A=B, p=q$ となるから (5) 式は少しだけ簡単になる。結合の種類としては 基本単位の並んでいる順序だけで区別すると， $A B, B A, C C, A C, C A, B C, B C$ の7種となる。 $A B, B A$ はナイロン塩の単独縮合からでき, $C C$ も别の単一結合であるから， $A C$ (あるいはCA) と $B C$ (あるんは $C B$ ) だけが目的の共縮合結合に当る。

このような結合の数であるが, $A=B$ におんて, $A B$ 結合数は次のような総和になる。

$$
\begin{aligned}
N_{A B}= & \sum_{2}^{\infty} 2(n-1) A^{2}(2 A+C)^{n-2} \alpha^{n-1} \\
& \text { ただし } n \text {; 重合笶 }
\end{aligned}
$$

同椂にして得られた值を整理したのが（8）式である。

$$
\begin{aligned}
& N_{A B}=N_{B A}=2 A \cdot B \alpha=2 A^{2} \alpha \\
& N_{C C}=C^{3} \alpha \\
& N_{A C}=N_{C A}=N_{E \mathrm{C}}=N_{C B}=A C \alpha
\end{aligned}
$$

$N / \alpha$ (存在の割合) はもちろん最初の組成にのみ関係する。第1図に簢単に図示した。縮合物分子 の無秩序性はやはりナイロン塩:アミノ酸=1:1 のときにもっともはなはだしん。

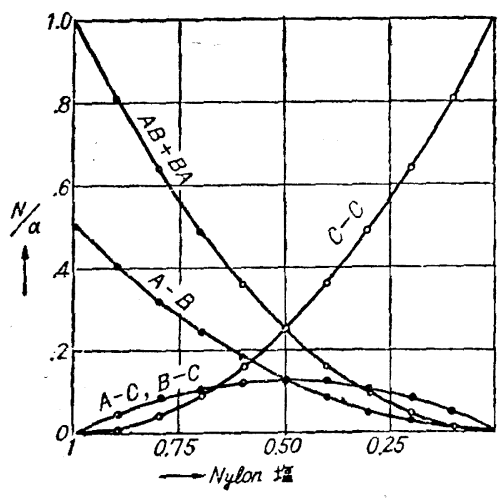

穿 1 図

\section{文献}

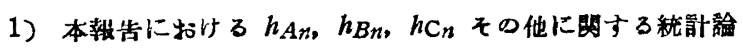
的歌算は当所长非策一氏によって行われた。絬果は一教子 る。これは「三成分線状缩合体の分子分布の統計的枯察」 として别に投轎された。

2) P. J. Flory: J. A. C. S. 581877 (1936) 著著(井 上) 本交 (6)-(1) 式 $h_{A n}$ \& Flory D (27) 式 (p.18 83) の $\Pi_{x}($ odd $-A) / x$ に当万。 $h_{A n}$ を同じ符号に蕾きなおすと，

$$
\begin{array}{r}
h_{A n}=p^{x-1} r^{x / 2}\left[\frac{(1-p)^{2} r^{\frac{1}{2}}}{1+r}\right] \\
\text { ただし } r=\frac{\mathrm{A}}{\mathrm{B}}, x=n
\end{array}
$$




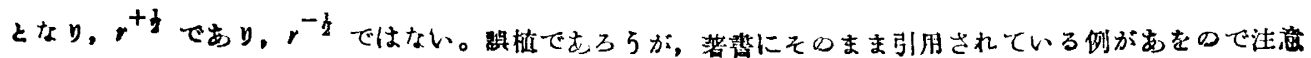
迄に。

第 5 報モノマーとのみ反応する繀合について

$$
\text { 井上良三・須本操。 }
$$

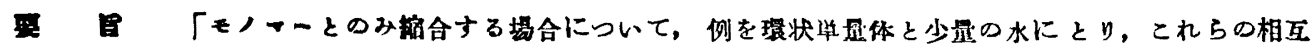

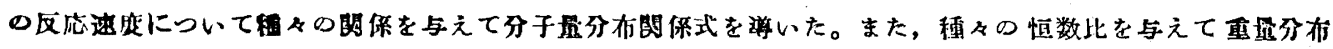
因をえがき，实确例と比較した。」

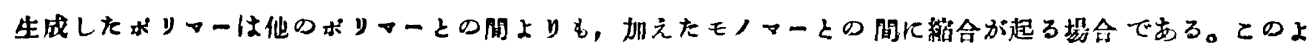
らなととが起るためには刃いる単盘体の化学楼造が他の生成分子のそれと哄なるところのものがなければな らないるのと考えられる。環状モノ、ーはこの典型的な例でむる。例えば,

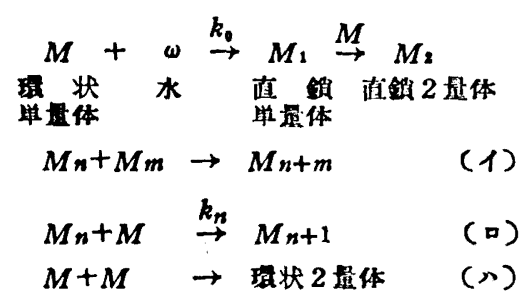

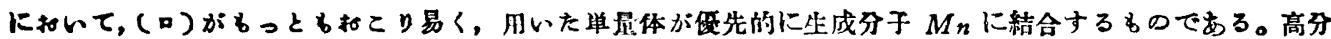
于合成をいら点てはをを制限することによって $\mathbf{~} M n$ を制限し5るので非管に効率の高い縮合反応である

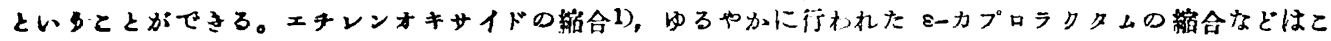
れに当るるのと思われるが, モの他古くLeuchs2)によって行われ，最近 Woodward 及び Schramm3)ゃ

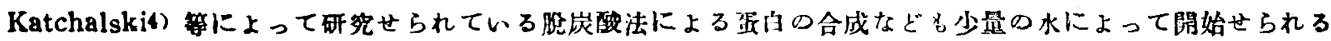

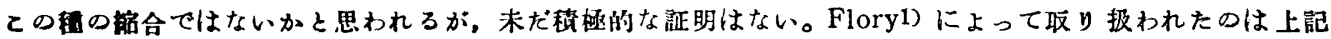
反度形式に扣いて速度恒数 $k_{0} \gg k_{n} ， k_{n}=$ 恒定の特殊な一例であるけれども， $k_{0}, k_{n}$ の相互の関保いかんに 上っては，得られる綰合物の分子贯分坊は典刑的な Poisson 分有からはずれ，分仿曲線は次第に平垚になっ

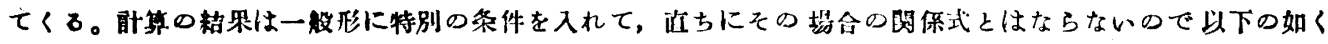
四っに分数して招く。

\section{【I〕 $k_{0} \ll k_{n}, k_{n}$ は $n$ に無関俕}

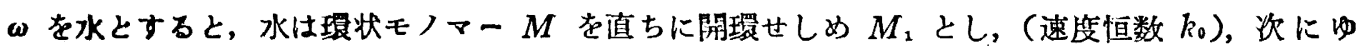
るやかに(速度堭数 $k_{n}=k$ ) $\mathrm{M}_{n}+\mathrm{M} \rightarrow \mathrm{M}_{n+1}$ がおこる。Flory によって行われた場合に外ならない が，著者による関係式も示しておく。

$$
\begin{aligned}
& \frac{d h_{1}}{d \alpha}=-x_{1} \\
& n \text { †1では } \frac{d h_{n}}{d \alpha}=x_{n-1}-x_{n} \\
& \} \\
& x_{n}=\frac{h_{n}}{\sum_{1}^{\infty} h_{n}}=\frac{h_{n}}{h_{00}}
\end{aligned}
$$

